\title{
QUALITY SERVICES AS A KEY FACTOR OF COMPETITIVENESS OF TRANSPORT COMPANIES
}

\author{
UDC: $005.6: 005.346]: 656$ \\ Review Scientific Paper \\ Srđan BOGETIĆ ${ }^{1}$, Marijana VIDAS BUBANJA², Snežana LEKIĆ ${ }^{2}$ \\ ${ }^{1}$ Belgrade Business School, 11000 Belgrade, 73 Kraljice Marije, Republic of Serbia. \\ E-mail: srdjan.bogetic@bbs.edu.rs \\ ${ }^{2}$ Belgrade Business School, 11000 Belgrade, 73 Kraljice Marije, Republic of Serbia. \\ Paper received: 02.07.2014.; Paper accepted: 04.09.2014.
}

\begin{abstract}
This paper deals with the question of the service quality as an important factor of transport companies in the process of improving competitiveness. Due to global competition and great opportunities that are offered to customers, transporting enterprises need to change their current relationship with the end consumer in order to improve the quality of offered services. Traffic enterprises have realized that improvement of the business processes comes with the use of modern ICT solutions and applications that will ensure that protection of the environment has been taken into account and the quality of service improved as well. Domestic traffic enterprises are not yet ready to accept the change of the way of conducting their business, which furtherly affects the quality of services, and they are still not prepared for the arrival of competition in the transport market.
\end{abstract}

Key words: customer satisfaction, quality services, competitiveness, green ICT.

\section{INTRODUCTION}

On the world stage there is the process of globalization, with a tendency of further attendance and the growing interdependence between the economy, industry and markets in an increasingly intense and constantly changing competition. Success in the world market is increasingly defined as the ability and the speed with which a company, industry, sector (or economy and society as a whole) innovate and become more productive. At the same time, innovation and productivity are related to the acceptance and application of new technological applications, especially in the field of information and communication technologies (ICT), organizational transformation and human resource structure that is based on an educated workforce (Bogetić et al, 2014).

Technological advances nowadays are particularly dynamic in the field of information and communication technologies (ICT), thus we can talk about transition to a new mode of growth, new civilizational context, which is defined as the knowledge society or information society. The new growth model is based upon intensity of information processes, resources, materials and products. Instead of the massive and homogeneous, it develops low-rate initial, heterogeneous and flexible production that allows diversified response to market demands. Separated functions in the production process are combined in an integrated interactive whole production, marketing and management. Dynamic and knowledge-based industries such as electronics, airline industry, pharmaceuticals, telecommunications, etc., are therefore becoming holders of growth (Vidas Bubanja, 2013).

That transport sector in this new development concept is facing all above mentioned challenges prove the results of analysis whether examination is done on a global, regional (EU) or the level of the national economy (Serbia). Work and development strategies of the transport sector today are increasingly abandoning classical solutions for individual modes of transport at the expense of the development of an integrated transport network. Integrated transport solutions 
favor the transport that is less harmful to the environment and stimulate the redistribution between different forms of transportation. This presupposes the development and introduction of new traffic management technologies based on ICT, development of dynamic databases and user awareness, development and application of new technologies, such as satellite positioning and navigation systems. All of this should be complementary to the physical infrastructure, which is a prerequisite to ensure the optimal use of transport networks. According to this approuch there is no longer the network of roads, railways, rivers, canals, sea routes, air corridors, but the individual networks that together form an integrated transport network (ITN).

\section{FACTORS OF COMPETITIVENESS OF ENTERPRISES IN THE REPUBLIC OF SERBIA}

For many years Serbian economy has had a problem with the productivity of labor. This was the result of an inadequate way of conducting their business, which was not based on market principles. The result were unrealistically high prices of certain products, which could not undergo on the global market. Therefore, domestic enterprises, in order to become successful on the international business scene, pour prices for the exports, and the difference in unproductive price was paid through high prices by domestic consumers. The market was protected with unrealistically high customs duties and other import restrictions (Đorđević et al, 2010).
The companies coming from transitional countries in general, and Serbia among them, have problems with quality of their business and production productivity. Inheritance of inefficiently productive systems and recession, common to all countries in transition, influence these companies and may be blamed for their insufficient competitive capacity. Serbian companies have been uncompetitive on international market for a long period. Low productivity and insufficient investment in achieving business quality are the main reasons for poor competitiveness of Serbian companies. This insufficient competitive ability has become more visible upon appearing of the world economic crisis (Đorđević et al, 2012).

According to the list of World Economic Forum for 2013-14, Serbia took $101^{\text {st }}$ place out of 148 analyzed countries. Since Serbia took $95^{\text {th }}$ place in $2012-13$ and $96^{\text {th }}$ in 2010 it is obvious that there is no progress in competitiveness. It is interesting that Serbia found itself between Algeria $\left(100^{\text {th }}\right.$ place $)$ and Guyana $\left(102^{\text {nd }}\right.$ place). Table 1 shows the ranking of ex-Yugoslav countries in the last five years, according to - WEF.

Considering the countries from near surroundings, Hungary takes 63 rd place, Bulgaria $57^{\text {th }}$, Romania $76^{\text {th }}$, Albania $95^{\text {th }}$ place. It is obvious that the effects of the World economic crisis have influenced the fall of competitiveness in all countries from the region. Taking into account the fact that Bosnia and Herzegovina improved its position on the list we can conclude that Serbian economy is the most uncompetitive in the region of West Balkans as well as in South East Europe. (Ćoćkalo et al, 2014).

Table 1: Ranking of West Balkan countries according to competitiveness in the period 2008-2013

\begin{tabular}{|l|c|c|c|c|c|c|}
\hline \multicolumn{1}{|c|}{ Country } & $\begin{array}{c}\text { Place in } \\
\mathbf{2 0 0 8}\end{array}$ & $\begin{array}{c}\text { Place in } \\
\mathbf{2 0 0 9 .}\end{array}$ & $\begin{array}{c}\text { Place in } \\
\mathbf{2 0 1 0 .}\end{array}$ & $\begin{array}{c}\text { Place in } \\
\mathbf{2 0 1 1 .}\end{array}$ & $\begin{array}{c}\text { Place in } \\
\mathbf{2 0 1 2}\end{array}$ & $\begin{array}{c}\text { Place in } \\
\mathbf{2 0 1 3}\end{array}$ \\
\hline Slovenia & 42 & 37 & 45 & 57 & 56 & 62 \\
\hline Montenegro & 65 & 62 & 48 & 60 & 72 & 67 \\
\hline Croatia & 61 & 72 & 77 & 76 & 81 & 75 \\
\hline Macedonia & 89 & 84 & 79 & 79 & 80 & 80 \\
\hline Serbia & $\mathbf{8 5}$ & $\mathbf{9 3}$ & $\mathbf{9 6}$ & $\mathbf{9 5}$ & $\mathbf{9 5}$ & $\mathbf{1 0 1}$ \\
\hline B and H & 108 & 109 & 102 & 100 & 88 & 87 \\
\hline
\end{tabular}

According to the business conditions list made by Forbes journal, Serbia takes $93^{\text {rd }}$ position out of 141 countries and the fall comparing to the last year is significant $\left(90^{\text {th }}\right.$ place $)$ - Table 2 .

Old technology, poor quality, unattractive packaging and high prices are the main reasons for lack of competitiveness of Serbian products. Least competitive is manufacturing industry, metal industry and electronics, in which for years there has been no technological reconstruction. Business people think that it is necessary to make customs and tax exemptions, reduction of administrative levies as well as prices for electrical energy, gas and fuels in order to increase competitiveness. It is also necessary to raise the level of technological 
facilities because the average age of machines in Serbia is 30 years. Comparing to the region it is a delay of 12 years (Đorđević et al, 2011).

Table 2: Position of Serbia according to individual criteria defining business condition

\begin{tabular}{|l|c|}
\hline Criteria Rank & Criteria Rank \\
\hline Monetary freedom & 123 \\
\hline Innovations & 122 \\
\hline Property Rights & 110 \\
\hline Tax burden & 113 \\
\hline Trade freedom & $80 \uparrow$ \\
\hline Technology & 57 \\
\hline Corruption & 77 \\
\hline Investor protection & 68 \\
\hline Personal freedom & 44 \\
\hline Red Tape & $37 \uparrow$ \\
\hline
\end{tabular}

Note: $\uparrow=$ increased compared to the previous period Source: The best countries for business. (October 2012)

\section{THE APPLICATION OF INFORMATION AND COMMUNICATION TECHNOLOGY AS THE BASIS FOR THE GROWTH OF MODERN ENTERPRISES COMPETITIVENESS}

As a "general purpose technology" or an "enabling technology" ICT are widely used in different domains, and have a profound effect on the entire economy. ICT use in business is not only becoming more pervasive, it is also progressing towards more advanced and sophisticated applications. The use and application of information and communication technologies in economic and social life is rapidly increasing throughout the world. For example, it is estimated that there are now some 6 billion mobile phone users and over 2.4 billion Internet users.

The role of ICT in economic development is in particular recognized for innovation, for competitiveness and for sustainability. The three domains are strongly interrelated. For example, if a company increases its energy efficiency ("sustainability"), it reduces costs and becomes more competitive (EC., ICT and E-Business for an Innovative and Sustainable Economy, 2010) .

All three domains of ICT impact - sustainability, competitiveness and innovation - are relevant at different levels: at the micro level of the individual company, the meso level of the industry and the macro level of the economy as a whole. Because of the meso and macro effects, industrial and innovation policy in advanced economies has for many years been paying close attention to ICT.
ICT production and diffusion in the economy have proved beneficial to innovation, productivity growth and economic development to an extent linked to the capacity of different economies to reap the benefits from ICT investment. That is, increases in ICT investment do not guarantee stronger multifactor productivity growth. General framework conditions, such as the degree of competition in a market, are likely to be of fundamental importance for innovative capacity of an economy. Statistical evidence suggests that the main role of ICTs as a contributor to productivity growth is their capacities to enable improvements in the way business processes are organized (Vidas-Bubanja et al, 2010).

On the micro-level studies made by the author Pilat (2005) suggest that the use of ICT does have positive impacts on firm performance, but primarily, or only, when accompanied by other changes and investments. This includes expenditure on skills and organizational change. This is also confirmed by many empirical studies that suggest that ICT primarily affects firms where skills have been improved and organizational changes have been introduced. Another important factor is innovation, since users often help make investment in technologies, such as ICT, more valuable through their own experimentation and invention. Without this process of "co-invention" (Bresnahan et al., 1996) which often has a slower pace than technological invention, the economic impact of ICT may be limited.

In order to analize ICT impact on firm performance, consideration of the following factors is important (Pilat, 2005)

a) Effective use of ICT requires appropriate skills,

b) Organizational change is key to making ICT work,

c) ICT effect are closely linked to competitive effects and the role of experimentation,

d) Firm size affects the impact of ICT,

e) The impacts of ICT use often only emerge over time, with certain time-lag.

According to E-Business Watch combination of different analytical approaches (such as micro and sectoral level data) can deliver more balanced evidence about ICT impact on innovation, competitiveness and growth of both companies and economies as a whole (see Table 3.) (EC, 2008). 
Table 3: The impact of ICT and e-business - micro and sector evidence

\section{Micro-data evidence:}

- Increasing strategic importance of e-business;

- ICT have become a general purpose technology they are widely used in all business functions. For many companies, e-business has become an important instrument for strategy implementation. The specific e-business objectives and applications, however, differ widely depending on the business model of a company, its size, and the market in which it operates;

- $55-70 \%$ of companies in all sectors expect that ICT will have a high or medium impact on their business. This is true in practically all areas, including primary functions (such as production, marketing and logistics) and support functions (such as controlling, human resources and accounting);

- ICT use is positively linked with an increase in turnover in all sectors studied. There is also a positive impact of ICT use on market shares. These points towards positive effects on firm performance.

\section{Sector-level analysis:}

- At the sector level, the direct contribution of ICT capital to productivity growth and industry growth is less pronounced;

- The sector in which ICT plays the greatest role is banking;

- Data about only modest impact of ICT capital on labor productivity indicates that outsourcing has been crucial to increasing labor productivity.

- Important driver for labor productivity growth (measured as gross production value per working hours) was intermediate inputs intensity;

- Electricity intensity is reduced by the use of communications devices, but is increased by IT (computers and software).

Source: European Commission, 2008.

\section{CHARACHERISTICS OF THE TRANSPORTATION SECTOR}

Transport and communication are essential human needs. It would be impossible to imagine the functioning of human communities without them today. Traffic comes as a result of transport and it is visible. Economic growth brings about a rise in various types of activities, increasing the need for transport and traffic accordingly. The thesis that modern communication reduces the need for conventional modes of transport is only partially true.

Modern communication is essentially a substitute for some movements. It also allows people to plan their time better and use it more efficiently. This usually means that increased activity during the day is enabled, which in turn affects the increase of mobility. The analysis of the position of the transport sector in the global business environment requires distinguishing three target segments of transport and setting traffic policy: local traffic, originally-targeted traffic and transit traffic (UNDP, 2008).

One of the key tasks of a state is, first of all, to harmonize the transport system within the country and develop the transport system which will enable high quality of local movement and similar quality in terms of access and links within the given territory, thus enabling a more balanced growth of all parts of the territory.

The second layer of traffic depends on the relations between the territory and its surroundings. This type of movement depends on the economic integration between the country and its closer and more distant surroundings, trade, tourism and other scopes of transport. This kind of movement also depends on the level of development of transport infrastructure which can service this kind of movement.

Local movement depends on the size of the territory relying predominantly on road and railroad infrastructure. Movement abroad, apart from road and railway infrastructure, rely also on airborne traffic (regional and distant). Transit movement in terms of distant passenger movement is turning increasingly to airborne traffic, and in terms of transport of goods to inter-modal transport.

\section{NEW ASPECTS REGARDING THE TERM OF QUALITY IN TRASNPORTATIONAL SERVICES}

In today's competitive environment, companies that want to survive must strive to improve their products and services. The concept of quality in traffic has been in practice for long, and transportation companies focussed receipts of services to the following performance: speed of transport, the price of transport, frequencies and availability. However, development of the transport market, as well as changes in the society, have lead to the realization that significant elements of the quality of transport services are road safety and traffic effects on the environment. The first element, traffic safety is more and more prominent in European Union which provides significant support for altertnative forms of transportation and programs that reduce pollution 
(Marco Polo), but also to the types of traffic that have a lower negative impact on the environment, such as river traffic.

It is believed that the use of ICT in transport can support the development of green and sustainable transport infrastructure in three ways (IISD, 2010):

1. by decreasing direct effects of transport sector on the environment through improved energy and materials efficiency, increased use of renewable energy sources, reduced use of toxic materials and improved recycling and end-of life disposal of used transport equipment;

2. by increasing the enabling effects of ICTs on the development of the green economy through improvements in the efficiency of production, distribution and consumption of transport services by reducing demand for energy and materials through the whole or partial substitution of virtual products and services for their physical equivalents; and through the dematerialization of human activities and interactions;

3. by supporting systemic effects that result in transformation of behavior, attitudes and values of individuals as citizens and consumers; economic and social structures; and governance processes.

However, on the company level in service sector it is increasingly important to use ICT solutions to support business processes. These solutions can streamline processes and have enormous potential for reducing $\mathrm{CO}^{2}$ emissions, because they improve the utilization of resources and allow them to be shared. ICT also permits in-depth monitoring of energy consumption and $\mathrm{CO}^{2}$ emissions throughout the value chain, so processes and organizational structures can be enhanced accordingly.

Transport systems represent about $26 \%$ of energy end-use in the EU. Many opportunities exist for improvements in energy efficiency and rationalization, notably through logistics. The focus is on the deployment of ICT to promote modal shift, notably on transport corridors for freight, and through the provision of multi-modal journey planners for passengers to enable significant reductions in congestion and savings (EC, 2009).

The most obvious benefits of Green ICT for service companies are reduced environmental impact and cost savings. Besides cost reduction a comprehensive Green ICT strategy offers many other benefits - appealing to all stakeholder groups: employee satisfaction increases, the company's standing with capital markets and with society as a whole improves, and the business can attract new customer groups.

A survey carried out by Forrester in 2009 to identify the three most important reasons for Green IT activities revealed that the principal motivation was to cut spending on energy (69\%). The second was to cut down on IT costs $(40 \%)$ and the third to improve image. The fourth reason cited was legal compliance $(15 \%)$. It is remarkable that cost considerations play an above-average role in the United States, while image and legal compliance are more important in Europe (ITU, 2012).

\section{THE CUSTOMER SATISFACTION AS A PREREQUISITE FOR SUCCESSFUL BUSINESS OPERATIONS OF TRANSPORT COMPANIES}

Customer satisfaction is a key element for survival of the enterprise on the market. Free competition in the transport market, requires from the companies in this sector intensive and continuous work on the creation of promotional activities that will attract new potential customers. On the other hand, more and more choices of transportation services of bidders from around the world imposed traffic companies need to devote special attention to existing customers as it becomes very important to preserve them and make them loyal with that achieved, follows the battle for new customers which is always more expensive since it must get and convert those customers to the status of the service user.

Transport companies that want to improve their relationship with the existing ones and to attract potential customers, need to constantly communicate with them. This is achieved by measuring customer satisfaction via surveys whose results indicate the degree of satisfaction of transport services users.

On the example of, "World Award airline companies" based on the Report of the world's airline company, which was created by the British company Skytrax, it can be seen how important is customer satisfaction and providing of quality transportation service. The quality of transport service is not just a period of flight, but the period of arrival to the airport, taking flights, baggage delivery, friendliness of the staff at the airport, the flight flow (engagement of staff in the body) and at the end the baggage claim period (the involvement 
of staff in airport). Airline companies that have failed to better communicate with customers on the market failed to achieve a sufficient level of profit and had to go bankrupt. They have been inherited by the airline companies that have managed to find new ways to communicate, such as Internet use and thus better tailor their services for the customers, by increasing transport volume and profit.

European Commission dealt with the issue of user satisfaction of transport services through the analytical report "Research on the satisfaction of passenger services by rail transport". In this survey, respondents were asked about satisfaction with various features of railway services, including train. This study showed the frequency of use of rail transport services in different EU member states. According to the survey, the highest number of respondents claimed to use the train less than once in month and this percentage ranges from $53 \%$ in the Czech Republic to $88 \%$ in Spain. However, one should not neglect the country with a high frequency of passenger rail transportation, such as Latvia, Slovenia and the three Benelux countries.

When talking about the satisfaction of railway passengers respodents on different characteristics of railway stations from the available characteristics, there are three with which passengers are most satisfied (The Gallup Organization, 2011) : the ease of purchasing tickets $79 \%$ (very - 47\%, rather - 32\%); provided information about the schedule of trains and platforms $76 \%$ (very - 23\%, pretty - 53\%) and personal security at the train station $(77 \%$ very $22 \%$, pretty $-55 \%$ ).

Apart from the station service, for passengers satisfaction it is also important the contribution of the quality of railway services and features of trains. Due to increase in demand of passengers, comfort and convenience must be improved, but also the speed of trains. The survey found that users are most satisfied (The Gallup Organization, 2011): with: personal safety level in trains $82 \%$ (very - 25\%, pretty - 57\%); length of travel time (commercial fibrin/traveling speed train) $78 \%$ (very - $22 \%$, pretty $-56 \%$ ) and the comfort of sitting $78 \%$ (very $-20 \%$, pretty $-58 \%$ ).

When talking about the quality of railway services, $47.3 \%$ of respondents are quite satisfied with the quality of facilities and services, versus $22 \%$ of those who are quite unhappy. When you look at the structure of the sample it can be seen that in a group of quite satisfied with the quality of content and service are surveyed persons from 25-39 years of age $(51.3 \%)$, living in urban $(47.1 \%)$ and rural $(48.8 \%)$ field. When looking at a sample of respondents who are not satisfied with the quality of content and services (22\%) it shows that the most represented are the young generation 15-24 years $(27.1 \%)$, living in urban $(22.3 \%)$ and urban (22.9\%) regions (The Gallup Organization, 2011).

The research of the European Commission has shown that the EU transport market in the area of passenger rail traffic is not on the same level of development, and that in some countries there is still insufficiently developed awareness of the need to adapt to the demands of passengers and a new form of business, where customer satisfaction foregrounds. Analysis by the member states of the European Union (EU) that participated in this study showed that users are from Finland (59\%), Spain (57.6\%), France (56.8\%), Portugal (56.6\%) and Sweden $(56.5 \%)$ are quite satisfied with the quality of facilities and services offered by the railway passenger traffic. On the contrary, people in Poland $(35.1 \%)$, Slovakia $(34.1 \%)$ and the Czech Republic (33.8\%) are quite unhappy with the quality of facilities and services of railways (The Gallup Organization, 2011).

\section{RELATIONSHIP OF DOMESTIC COMPANIES REGARDING THE QUALITY OF TRANSPORT SERVICES}

The issue of customer satisfaction with traffic services stays still with inadequate attention from domestic enterprises. The reason for this lies in the fact that many companies are still in a monopoly position, and they do not have a great need to think about customer satisfaction. Also, for years there were wrong and under-investment in some domestic companies such as Serbian Railways and JAT and the result is a big, dysfunctional and uncompetitive systems with which the state does not know what to do.

However, in areas where there has been a liberalization of the market, domestic enterprises have shown high interest to the user. As a result, these companies, such as Telekom Srbija to PTT Serbia, are becoming competitive, both on the domestic and regional market and are ready for new investment and the development of new services (Bogetić et al., 2013). 
Telekom Serbia has realized in the right moment the importance of customer satisfaction and thus successfully prepared for a period of market liberalization in the telecommunications field. This company, in spite of a dominant position in one area of business (fixed telephony) decided that key elements of their business policy are the customer and its pleasure. That is the purpose of setting up this issue at the highest level within its organizational structure created in the Directorate for Commercial jobs four functions: The function for marketing and sales, service management function, the function for customer care and the wholesale and multimedia. All functions have the same goal - to create satisfied and loyal customers, with a desire to turn them into profitable customers. Profitable customer means a person, household or company whose revenues over time exceed the costs that the company spent for attracting, selling and serving that customer.

In order to get closer to its customers, recognize their needs better and respond to those needs in the best possible way, as a priority task Telekom joined segmenting users in relation to the services they intended. As part of the Department of Commercial Affairs, functions for sales and marketing Telekom organized: Sector for residential customers, Sector sales business customers and sell additional services sector.

Successful segmentation and personalization of services Telekom based on the introduction of CRM (customer relationship management) technology management relationships with consumers. CRM integrates all the information that the sales, service and marketing teams know about consumers in order to get the whole view of the relationship with the consumer, assess the value of individual consumer, identifying those to whom it is best to target. Telekom Srbija performs all activities related to CRM within the Department of Marketing, Customer Service CRM, the Division of IT development and integration and CRM service support.

Besides Telekom, public company Post of Serbia has also taken several years ago extra activity in order to improve their business with the help of "Methodologies for monitoring the quality of the postal service." According to the methodology the quality of postal services is determined on the valuation base satisfying the following criteria (PTT Official Gazette, 2010): the availability of postal services; speed and reliability of the transmission of shipments; security of shipments; efficiency in resolving complaints; satisfaction and awareness of service users; level of standardization; typification and organizational climate and employee motivation.

Measuring customer satisfaction with traffic services for PE Post of Serbia is one of the key elements in the process of achieving continuous improvement of the quality of the business. Thanks to the information obtained from users who were previously analyzed, companies can measure and monitor customer satisfaction with services.

The information provided by the user includes the following segments (PTT Official Gazette, 2010): research and market needs depending on the type of user, the analysis of user expectations before using the postal service, measuring the level of satisfaction after the use of postal services.

Table 4 shows a comparison of data for the period 2010-2013 year, in the mean grade of satisfaction of service users. According to the methodology adopted by PE Post of Serbia degree of satisfaction with the service user is satisfactory if the average score of greater than 3.75 in the situation when evaluating range from 1 to 5 . Analysis showed that in this period the degree of satisfaction of users of postal services has also grown. The overall average evaluation of customer satisfaction in the 2010th was 4.20, and in the 2011.- 4.36, which is for 0,61 higher than the minimum prescribed level of satisfaction of users of postal services (3.75).

The survey also dealt with ranking of Serbian Post in several parameters: the trust and reliability, variety of services, quality and modernity (Table 5). Fortified growth of all monitored parameters shows the tendency of PE Post of Serbia company to work on continuous improvement of the quality of its services and the improvement of its business.

Among other things, testing followed user satisfaction with the availability of mail and postal box. It has also analyzed prices as well as the speed and security of the transmission of postal shipments. In both areas of research, parameters showed generally rising trend which confirms that the PE Post of Serbia identified key areas in which they need to act and build satisfaction and trust of its users (Tables 6 and 7).

As can be seen in Table 7 there is growth in almost all the parameters that were evaluated in the survey, even the security of sent shipments, which 
had a decline in 2011, in the the next two years improved.

Surveyed users of postal services had the opportunity to evaluate their Post office and data for all four years in almost all parameters were good. However, what constitutes a problem for users of postal services is inefficient resolving of complaints, which represents longtime problem. The mean average value is greater each year than the previous, but there are disadvantages that must be corrected.

Table 4: Average level of service user satisfaction in 2010 and 2013.

\begin{tabular}{|l|c|c|c|}
\hline Service Parameters & $\mathbf{2 0 1 0}$ & $\mathbf{2 0 1 1}$ & $\mathbf{2 0 1 3}$ \\
\hline Reliability & 4.46 & 4.62 & 4.75 \\
\hline Speed & 4.33 & 4.56 & 4.77 \\
\hline The range of services & 4.37 & 4.50 & 4.58 \\
\hline Price & 3.69 & 3.84 & 4.08 \\
\hline Manner of Service & 4.28 & 4.41 & 4.58 \\
\hline
\end{tabular}

Source: Report on the condition of the quality on Postal Traffic in 2010 and 2011. www.posta.rs, p. 18:19

Table 5: Ranking of Serbian Post

\begin{tabular}{|l|c|c|c|c|}
\hline Service Parameters & $\mathbf{2 0 1 0}$ & $\mathbf{2 0 1 1}$ & $\mathbf{2 0 1 2}$ & $\mathbf{2 0 1 3}$ \\
\hline Trust and reliability & 4,46 & 4,49 & 4,55 & 4,55 \\
\hline The diversity of services & 4,37 & 4,50 & 4,57 & 4,58 \\
\hline Quality & 4,28 & 4,31 & 4,37 & 4,45 \\
\hline Modernity & 3,98 & 4,04 & 4,13 & 4,24 \\
\hline Mean average value & 4,27 & 4,34 & 4,40 & 4,46 \\
\hline
\end{tabular}

Source: Report on the condition of the quality on Postal Traffic for the 2011, www.posta.rs, p. 19

Table 6: Satisfaction with availability

\begin{tabular}{|l|c|c|c|c|}
\hline Service Parameters & $\mathbf{2 0 1 0}$ & $\mathbf{2 0 1 1}$ & $\mathbf{2 0 1 2}$ & $\mathbf{2 0 1 3}$ \\
\hline Post offices & 4.52 & 4.48 & 4.50 & 4.50 \\
\hline Mailbox & 4.00 & 4.22 & 4.36 & 4.37 \\
\hline Post offices locations & 4.38 & 4.41 & 4.50 & 4.50 \\
\hline Mean average value & 4.30 & 4.37 & 4.46 & 4.46 \\
\hline
\end{tabular}

Source: Report on the condition of the quality on Postal Traffic for the 2011th year, www.posta.rs, p. 19

Table 7: Empirically ranking of Serbian Post

\begin{tabular}{|l|c|c|c|c|}
\hline Aspects & $\mathbf{2 0 1 0}$ & $\mathbf{2 0 1 1}$ & $\mathbf{2 0 1 2}$ & $\mathbf{2 0 1 3}$ \\
\hline Prices of postal services & 3.69 & 4.48 & 3.82 & 4.08 \\
\hline Security of sent shipments & 4.46 & 4.22 & 4.67 & 4.75 \\
\hline Deadlines transmission (speed) & 4.33 & 4.41 & 4.65 & 4.77 \\
\hline Mean average value & 4.16 & 4.37 & 4.38 & 4.53 \\
\hline
\end{tabular}

Source: Report on the condition of the quality on Postal Traffic for the 2011th year, www.posta.rs, p. 19

Table 8: Empirical ranking of Post

\begin{tabular}{|l|c|c|c|c|}
\hline The criteria & $\mathbf{2 0 1 0}$ & $\mathbf{2 0 1 1}$ & $\mathbf{2 0 1 2}$ & $\mathbf{2 0 1 3}$ \\
\hline Hours & 4.46 & 4.63 & 4.75 & 4.82 \\
\hline Opening hours on weekends & 4.31 & 4.46 & 4.65 & 4.74 \\
\hline Availability of counters during the crowds & 3.51 & 3.61 & 3.72 & 3.92 \\
\hline Courtesy and professionalism of employees & 4.33 & 4.41 & 4.48 & 4.57 \\
\hline The possibility of obtaining fast and accurate information & 4.34 & 4.40 & 4.52 & 4.62 \\
\hline The efficiency of resolving complaints & 4.09 & 3.98 & 3.95 & 3.96 \\
\hline $\begin{array}{l}\text { Overall rating inside of the post (atmosphere, hygiene, } \\
\text { whole ventilation system) }\end{array}$ & 4.10 & 4.04 & 4.21 & 4.36 \\
\hline The mean average value & 4.16 & 4.22 & 4.32 & 4.43 \\
\hline
\end{tabular}

Source: Report on the condition of the quality on Postal Traffic for the 2011th year, www.posta.rs, p. 19

This example of PE Post of Serbia highlights the importance of continuous monitoring of customer satisfaction of service companies in order to run their business successfully and profitably. Comparing the data of respondents from all four years $(2010,2011,2012,2013)$ it is visible that the company has a constant tendency of growth of average value, which indicates that the company is working to improve the quality of postal services. In the earlier period there were problems that Post 
of Serbia encountered with and which resulted in the improvement of the business organization and relationships with the users of their services.

\section{CONCLUSION}

In today's competitive environment, companies that want to survive have to strive to improve their products and services. If as a means for defining fields improvement using results from customer satisfaction surveys, it is expected that the results will improve to be more in line with the requirements of the user. The company must understand the expectations and preferences of their customers, and use them as a guide to achieve competitive advantage (Kostić, 2010).

Traffic is a specific activity that is unlike other activities and has a different view on the quality of service provided. That is, the quality of traffic service is hardly quantifiable and it is impossible to test it before using, which shows that the quality of this service is highly and extremely complex. The literature in the field of traffic on the quality of traffic service usually involves the following: "..... as a set of commercial and technical activities as a whole should provide satisfaction of users' demands, reflecting the quality of the simultaneous processes of work in the production of these services, which requires permanent control of all processes and continually improving the organization and functioning of the system" (Kostadinović, 2008).

That customer satisfaction represents the precondition for successful operation of enterprises from the traffic sector, it is best confirmed by the activities of these companies in the EU, where customer satisfaction is regularly monitored and based on the work results of companies. Domestic traffic enterprises still do not pay enough attention to customers and their satisfaction, as the monopoly position of some traffic systems so far allowed. The companies that experienced the conditions of market liberalization were first to realize that competition brings serious challenges and that local traffic companies must set focus of their businesses to customer satisfaction first. Activities of Telekom Serbia are an excellent example of this change in companies management - by usage of CRM technology it can know its users better and effectively manage relationships with them. Also, a public company Post Serbia has through the adoption of "Methodologies for monitoring the quality of the postal service", impacted and improved the quality of service provided to users. In this way, the company has shown that customer care and quality of service offered, is their strategic goal. In fact, thanks to used methodology, PE Post of Serbia has measured for four years, customer satisfaction traffic services in order to achieve continuous quality improvement of its business. Based on the data obtained from this research the company has received the parameters on which it bases boost of the labor process and improved customer satisfaction with services.

\section{REFERENCES}

Bogetić, S., Lekić, S., \& Ranđić, D. (2013). Satisfaction of service users in order to improve the competitiveness of traffic enterprise. Proceedings of the Conference JUSK ICQ 2013 - Sixth Conference Development of business excellence and competitiveness of domestic enterprises. Belgrade: JUSK.

Bogetić, S., Vidas Bubanja, M., \& Lekić, S. (2014). Service quality improvement as a precondition for business excellence of companies in transport sector. Proceedings of the IV International symposium Engineering Management and Competitivness (EMC 2014) (pp. 43-49). Zrenjanin: TF Mihajlo Pupin.

Bresnahan, T. F., \& Greenstein, S. (1996). Technical Progress and Co-Invention in Computing and the Use of Computers. In M. N. Bailey (Ed.), Brookings Papers on Economic Activity: Microeconomics (pp. 1-77). Washington, DC: Brookings Institution.

Ćoćkalo, D., Bešić, C., Đorđević, D., \& Bogetić, S. (2014). Socially Responsible Business and Competitiveness in Serbia - Attitudes of Students. Sovremennaa Ekonomika - Problemy, tendenci, perspektivy, 10(1), 141-159.

Đorđević, D., Ćoćkalo, D., \& Bogetić, S. (2010). Analiza konkurentske sposobnosti domaćih preduzeća u svetlu novih globalnih tokova. Zbornik radova Konferencije JUSK ICQ 2010 - Treća konferencija Razvoj poslovne izvrsnosti $i$ konkurentnost domaćih preduzeća (pp. 332-335). Beograd: JUSK.

Đorđević, D., Ćoćkalo, D., \& Bogetić, S. (2011). New Model of Competitiveness Management and Development of Domestic Enterprises. Paper presented at the UASQ ICQ 2011 - International Convention on Quality, Belgrade, Serbia.

Đorđević, D., Ćoćkalo, D., Sajfert, Z., \& Klarin, M. (2012). An Analysis of the Clean Technologies Sector Impact in Regional Economic Development. Metalurgia International, 17(12), 129-133.

European Commission, (2009), Communication on Mobilising Information and Communication Technologies to faciliate the transition to an energyefficinet, low-carbon economy, Brussels, COM (2009) 111 final, March

European Commission, E-Business Watch, (2008), EBusiness in Europe-2008, Industry perspectives on 
e-business development and ICT impact, Brussels, 12.

European Commission, ICT and E-Business for an Innovative and Sustainable Economy, (2010.) 7th Synthesis Report of the Sectoral e-Business Wacth, Brussels

Flash EB Series 326, (2011), Survey on passengers' satisfaction with rail services - Analytical Report, The Gallup Organization, Directorate - General Mobility and Transport and coordinated by Directorate - General Communication June

IISD, (2010), The Digital Economy and the Green Economy: Opportunities for strategic synergies, International Institute for Sustainable Development, Retrieved October, from: http://www.iisd.org/pdf/2010/com_digital_economy. pdf.

ITU, Goverment of Canada and Prompt, (2012), Why Green ICT: Challange or Opportunity?, 7th ITU Symposium on ICTs, the environmnet and climate change, Montreal, Canada.

Kostadinović, G. (2008). Marketing u saobraćaju. Niš: Visoka škola strukovnih studija za menadžment u saobraćaju.

Kostić, E. (2010). Customer satisfaction measurement services to the example of Delta DMD. Sema Serbian Society for Marketing Research, 41(4), 268276.
Pilat, D. (2005). The economic impacts of ICT-lessons learned and new challenges. Paper presented at the Eurostat Conference "Knowledge Economy Challenges for Measurement.

Report on the status of the quality of postal services for the 2010th year, (2010), http://www.posta.rs/

Report on the status of the quality of postal services for the 2013th year, (2013), http://www.posta.rs/

The methodology for monitoring the quality of the postal service, (2010) PTT Official Gazette no. 618

The Report on the state of the quality of postal services for the 2011th year, (2011), http://www.posta.rs/

UNDP, (2008.), Human Development report Serbia 2008, Belgrade, 93-98

Vidas Bubanja, M. (2013). Inovativnost kao osnova konkurentnog poslovanja preduzeća Zbornik radova Konferencije JUSK ICQ 2013 - Šesta konferencija Razvoj poslovne izvrsnosti i konkurentnost domaćih preduzeća. Beograd: JUSK.

Vidas-Bubanja, M., \& Knežević, B. (2010). E-Business as a Key Factor for Innovation, Competitiveness and Growth of Companies. Proceedings of the 33rd International Convention MIPRO 2010, Digital Economy (pp. 42-46). Opatija, Croatia.

World Economic Forum, The Global Competitiveness Report (2008-2013), http://www.weforum.org/reports/globalcompetitiveness-report-2013-2014 